\title{
Effects of Garlic and Thyme Extracts on Growth Performance and Carcass Characteristics of Broiler Chicks
}

\author{
Anvar Amouzmehr ${ }^{1}$, Behrouz Dastar ${ }^{1}$, Jalil Ghassemi Nejad ${ }^{2}$, Kyung Il Sung ${ }^{2}$, Jayant Lohakare ${ }^{3}$ and Fereidoun Forghani $^{4}$ \\ ${ }^{1}$ Gorgan University of Agricultural Sciences and Natural Resources, Gorgan, Iran, ${ }^{2}$ Department of Animal Life System, \\ College of Animal Life Sciences, Kangwon National University, Chuncheon, Republic of Korea, ${ }^{3}$ Department of Animal \\ Biotechnology, College of Animal Life Sciences, Kangwon National University, Chuncheon, Republic of Korea, ${ }^{4}$ Department \\ of Food Science and Biotechnology and Institute of Bioscience and Biotechnology, Kangwon National University, Chuncheon, \\ Republic of Korea
}

\begin{abstract}
A total of 800 one-day-old chickens (Cobb 500) were obtained from a local hatchery and allocated randomly to five dietary treatments. This study conducted for $42 \mathrm{~d}$. Treatment groups included 1) CON (control), 2) T0.3 (0.3\% of thyme extract), 3 ) T0.6 $(0.6 \%$ of thyme extract), 4) G0.3 (0.3\% of garlic extract) and 5) G0.6 (0.6\% of garlic extract). Thyme extract included $90 \mu \mathrm{g} / \mathrm{ml}$ Carvacrol and $400 \mathrm{mg} / \mathrm{ml}$ thymol while garlic extract included $100 \mathrm{mg} / \mathrm{ml}$ elastin. There were no significant effects among the treatments on weight gain, feed intake and feed conversion ratio over the entire trial. Also, no significant differences were observed between CON group and other treatments in plasma parameters (cholesterol, triglyceride and HDL) and hematocrit. Sex of chickens had no effect on blood parameters. Supplementation of herb extracts did not affect carcass characteristics including carcass yield, breast, thigh and abdominal fat. There were no significant differences observed in carcass characteristics between males and females fed with different levels of herb extracts. In conclusion, supplementation of garlic and thyme extracts as feed additives at two levels of 3 and $6 \%$ in the present study did not improve performance and carcass traits of broiler chicks.
\end{abstract}

(Key words : Additive, Antibiotics, Garlic, Herbal extract, Thyme)

\section{INTRODUCTION}

Antibiotics have been extensively used as feed additives and growth promoters in animal feed industry. The use of antibiotics as feed additives is hazardous due to crossresistance and multiple resistances of pathogens (Schwarz et al., 2001). Therefore, European Union has banned the application of most of antibiotics in poultry diets. Thus, during the past decade many studies investigated the use of new and promising feed-additives including probiotics, prebiotics, enzymes, and plant extracts in animal feeding (Sarica et al., 2005; Hernandez et al., 2004; Demir et al., 2003).

Herbs have been used for natural therapy as pharmaceuticals; however, only in recent years aromatic plants and their extracts were introduced to the animal feeding (Mikulski et al., 2008). Some herbs or herbal extracts can beneficially affect feed intake, secretion of digestive tract juices and immune system of animals (Mikulski et al., 2008).
Essential oils are derived mainly from herbs and spices and their purified compounds have antimicrobial properties (Faleiro et al., 2003).

Reports on the effect of herbal extracts on broiler performance are inconsistent. Cross et al. (2002) indicated that garlic and thyme extracts did not have any significant effect on the broiler performance. Bassett (2000) reported that adding herbal essential oils to the feed or water increases feed conversion and weight of broiler chickens. Some researchers reported that herb extracts have antibacterial characteristics (Azaz et al., 2002; Dorman and Deans, 2000), antioxidant activity (Botsoglou et al., 2002 and 2004), and also enhance digestibility by stimulating endogenous enzyme activity and facilitating nitrogen absorption(Gill, 2001). To the best of author's knowledge there is no report on the effect of indigenous Iranian herbal extracts on the broiler performance. Therefore, the aim of the present study was to investigate the effect of two indigenous herbal extracts: garlic (Allium Sativum) and thyme (Thymus Vulgaris) on the

* Corresponding author: Kyung-Il Sung, Department of Animal Life System, College of Animal Life Sciences, Kangwon National University, Chuncheon 200-701, Korea. Tel: +033-250-8635, Fax: 033-242-4540, E-mail: kisung@kangwon.ac.kr 
broilers performance, carcass composition, and plasma and abdominal fat pad were collected and weighed. parameters.

\section{MATERIALS AND METHODS}

A total of 800 one-day-old chickens of the Cobb500 strain were obtained from a local hatchery. The birds were randomly allotted to 20 floor pens with 40 males or females per pen. Each four pens were randomly selected to receive one treatment of the five diets.

Two Iranian indigenous herbal extracts, garlic (Allium Sativum) and thyme(Thymus Vulgaris) were added to a diet based on corn and soybean meal (CON diet). Both the herbal extracts were used in two different doses $(0.3$ and 0.6 percent) in the $\operatorname{diet}($ Table-1). Feed and water were provided ad libitum. Feed intake and BW were recorded at 14 day intervals during the 42 days study. Birds were killed by cervical dislocation on day 42 of the experiment, and carcasses were weighed and dissected. Thigh and breast meat

Table 1. Ingredients, and nutrient composition of experimental diets

\begin{tabular}{|c|c|c|}
\hline \multicolumn{3}{|l|}{ Ingredients (\%) } \\
\hline & $1-21 \mathrm{~d}$ & $22-42 d$ \\
\hline Corn & 61.5 & 57.5 \\
\hline Soybean meal $(48 \% \mathrm{CP})$ & 22.1 & 36.3 \\
\hline Rape seed meal & 10.0 & \\
\hline Soybean oil & 2.91 & 1.93 \\
\hline Calcium carbonate & 1.33 & 1.37 \\
\hline Dicalcium phosphate & 1.13 & 1.64 \\
\hline Salt & 0.34 & 0.47 \\
\hline Mineral premix 1 & 0.25 & 0.25 \\
\hline Vitamin premix 2 & 0.25 & 0.25 \\
\hline D, L-Methionine & 0.06 & 0.23 \\
\hline L-Lysine & 0.07 & \\
\hline Vitamin E & 0.02 & 0.02 \\
\hline Salinomycin & 0.05 & 0.05 \\
\hline \multicolumn{3}{|l|}{ Analyzed nutrient content } \\
\hline Metabolizable energy $(\mathrm{kcal} / \mathrm{kg})$ & 3000 & 2890 \\
\hline Crude protein & 18.7 & 20.8 \\
\hline \multicolumn{3}{|c|}{$\begin{array}{l}\text { Composition of mineral premix (per } \mathrm{kg} \text { of premix): } \mathrm{Mg}, 50,000 \\
\mathrm{mg} \text {; Fe, } 25,000 \mathrm{mg} \text {; } \mathrm{Zn}, 50,000 \mathrm{mg} \text {; Cu, 5,000 mg; I, } 500 \mathrm{mg} \text {; Se, } \\
100 \mathrm{mg} \text {. Composition of vitamin premix (per kg of premix): } \\
\text { vitamin A, } 3,500,000 \mathrm{IU} ; \mathrm{D}_{3}, 1000,000 \mathrm{IU} ; \mathrm{E}, 9,000 \mathrm{IU} ; \mathrm{K}_{3}, 1000 \\
\mathrm{mg} \mathrm{B}_{1}, 900 \mathrm{mg}, \mathrm{B}_{2}, 3,300 \mathrm{mg}, \mathrm{B}_{3}, 5,000 \mathrm{mg}, \mathrm{B}_{5}, 15,000 \mathrm{mg} ; \mathrm{B}_{6}, \\
150 \mathrm{mg} \text {, B, } 500 \mathrm{mg} ; \mathrm{B}_{12}, 7.5 \mathrm{mg} \text {; choline, } 250,000 \mathrm{mg} ; \text { Biotin, } \\
500 \mathrm{mg} \text {. }\end{array}$} \\
\hline
\end{tabular}

\section{Sample collection and sample preparation}

On day 42, a male and female from each pen were selected for blood sampling. One $\mathrm{ml}$ of blood was sampled in an EDTA-tube, mixed vigorously, and centrifuged for 10 minutes at $2000 \mathrm{rpm}$ (Hettich EPA30, Germany) to obtain plasma. The erythrocyte count was performed on EDTA mixed blood (Sysmex K21, UK-Japan) and plasma total lipid was obtained using an auto analyzer (Mindrey PM 200, China).

\section{Data analysis}

Data were analyzed using SAS (1999). A general linear model was used to analyze the effect of diets on the broilers performance. The effects of diet and sex on the carcass composition, blood lipids and hematocrit were analyzed by exploiting a factorial design.

\section{RESULTS AND DISCUSSION}

Supplementation of 0.3 and $0.6 \%$ of thyme or garlic extract diet did not affect the feed intake, weight gain, and feed conversion ratio (FCR) (Table-2). These results are in accordance with the report of Sarica et al. (2005) that reported chickens fed with the garlic and thyme extract containing diet had the same weight gain with CON group. Cross et al. (2002) also reported that there is no significant difference in weight gain of chickens fed with garlic and thyme extract compared to the CON group. Also, Konjufca et al. (1997), Botsoglu (2002 and 2004) and Bolukbasi et al. (2006) reported non-significant effect of garlic powder supplementation on weight gain of broiler chickens.

However, some studies like Thakar et al. (2004) showed that thyme extract powder decreased broiler chicken weight compared with the CON, whereas others reported that use of essential herb oils increased weight in broiler chicken at the end of 42 days (Alçiçek et al., 2003) and improved FCR in broiler chickens (Bolukbasi et al., 2006 Cross et al., 2002). This result is different from other studies showing no significant effect of garlic and thyme extracts on the feed consumption and FCR in broiler chickens (Sarica et al., 2005; Thakar et al., 2004 Tucker, 2002 Williams and Losa, 2001 Hertrampf, 2001 Bakalli et al., 1997; Konjufca et al., 
Table 2. Effect of plant extracts on broiler performance

\begin{tabular}{|c|c|c|c|c|c|c|}
\hline & \multirow{2}{*}{$\mathrm{CON}$} & \multicolumn{2}{|c|}{ Thyme extract } & \multicolumn{2}{|c|}{ Garlic extract } & \multirow{2}{*}{ P-value } \\
\hline & & T $0.3 \%$ & T $0.6 \%$ & G $0.3 \%$ & G $0.6 \%$ & \\
\hline \multicolumn{7}{|l|}{ Gain } \\
\hline $1-14 \mathrm{~d}$ & $337.3 \pm 11.2$ & \pm 4.5 & $335.0 \pm 4.0$ & $324.0 \pm 16.4$ & $336.9 \pm$ & 0.16 \\
\hline $14-28 \mathrm{~d}$ & $695.5 \pm 13.6$ & \pm 10.5 & $627.5 \pm 11.1$ & $703.3 \pm 7.2$ & $667.3 \pm 13.0$ & 0.12 \\
\hline $28-42 \mathrm{~d}$ & $920.1 \pm 34.8$ & $953.2 \pm 31.1$ & $880.1 \pm 34.8$ & $916.6 \pm 30.4$ & $934.2 \pm$ & 0.58 \\
\hline $1-42 \mathrm{~d}$ & $1927.9 \pm 38.4$ & $1988.8 \pm 21.9$ & $1897.7 \pm 38.2$ & $1944.1 \pm 29.8$ & $1938.4 \pm 27.5$ & 0.41 \\
\hline \multicolumn{7}{|l|}{ Feed intake } \\
\hline $1-14 \mathrm{~d}$ & $468.12 \pm 12.0$ & $469.5 \pm 1.5$ & $462.9 \pm 13.6$ & $454.4 \pm 20.7$ & $463.5 \pm 15.3$ & 0.92 \\
\hline $14-28 \mathrm{~d}$ & $1282.6 \pm 22.0$ & $1312.7 \pm 23.9$ & $1269.0 \pm 16.25$ & $1315.8 \pm 39.4$ & $1267.2 \pm 354$ & 0.46 \\
\hline $28-42 \mathrm{~d}$ & $1995.0 \pm 36.7$ & $2065.9 \pm 44.0$ & $1933.0 \pm 44.5$ & $1948.8 \pm 61.4$ & $2019.7 \pm 502$ & 0.75 \\
\hline $1-42 \mathrm{~d}$ & $3745.4 \pm 62.0$ & $3848.0 \pm 59.2$ & $3664.9 \pm 50.0$ & $3755.0 \pm 83.4$ & $3750.4 \pm 704$ & 0.63 \\
\hline \multicolumn{7}{|c|}{ Feed conversion ratio } \\
\hline $1-14 \mathrm{~d}$ & $1.38 \pm 0.01$ & $1.40 \pm 0.02$ & $1.39 \pm 0.01$ & $1.40 \pm \quad 0.02$ & $1.37 \pm$ & 0.15 \\
\hline $14-28 \mathrm{~d}$ & $1.85 \pm 0.05$ & $1.89 \pm 0.05$ & $1.89 \pm 0.02$ & $1.90 \pm 0.08$ & $1.90 \pm$ & 0.92 \\
\hline $28-42 \mathrm{~d}$ & $2.18 \pm 0.05$ & $2.17 \pm 0.05$ & $2.20 \pm 0.04$ & $2.17 \pm 0.1$ & $2.14 \pm$ & 0.97 \\
\hline $1-42 \mathrm{~d}$ & $1.92 \pm 0.01$ & $1.94 \pm 0.01$ & $1.93 \pm 0.01$ & $1.97 \pm 0.08$ & $1.93 \pm$ & 0.92 \\
\hline
\end{tabular}

1997 Langhout, 1997). Our results also showed no significant effect of garlic and thyme extracts on performance and carcass traits of broilers.

Non-significant effect of herb extracts of garlic and thyme on the performance of broiler chickens may be due to the hygienic situation of experiment. In this study birds were kept in clean disinfected environment following all hygiene regulations. Around 10 birds stayed in one square meter due to flock accumulation. This tendency may inhibit growth and feed conversion ratio. It is reported that growth promoter combinations such as antibiotics (Knarreborg et al., 2002), probiotics (Patterson and Barkholder, 2003) and herb additives (Sarica et al., 2005) result in preventing the growth of pathogens by competitive elimination mechanism. In this trial, the use of growth promoter combinations may have had desirable effect on bird's performance.

Table-3 shows the effect of herbal extracts on cholesterol $(\mathrm{mg} / \mathrm{dl})$, triglycerides $(\mathrm{mg} / \mathrm{dl})$ and $\mathrm{HDL}(\mathrm{mg} / \mathrm{dl})$ concentrations

Table 3. Effect of the plant extracts on blood lipids and hematocrit of broilers

\begin{tabular}{|c|c|c|c|c|}
\hline & Cholesterol (mg/dl) & Triglycerides $(\mathrm{mg} / \mathrm{dl})$ & $\mathrm{HDL}(\mathrm{mg} / \mathrm{dl})$ & Hematocrit (\%) \\
\hline $\mathrm{CON}$ & $106.0 \pm 5.9$ & $98.0 \pm 13.6$ & $59.0 \pm 4.8$ & $28.0 \pm 1.3$ \\
\hline \multicolumn{5}{|c|}{ Thyme extract } \\
\hline Т $0.3 \%$ & $108.0 \pm 8.7$ & $102.0 \pm 7.9$ & $62.0 \pm 3.8$ & $29.0 \pm 0.5$ \\
\hline Т $0.6 \%$ & $111.0 \pm 8.2$ & $93.0 \pm 6.9$ & $63.0 \pm 4.9$ & $29.0 \pm 0.8$ \\
\hline \multicolumn{5}{|c|}{ Garlic extract } \\
\hline G $0.3 \%$ & $106.0 \pm 8.4$ & $83.0 \pm 7.8$ & $61.0 \pm 5.7$ & $29.0 \pm 0.5$ \\
\hline G $0.6 \%$ & $115.0 \pm 7.5$ & $103.0 \pm 7.5$ & $67.0 \pm 5.2$ & $29.0 \pm 0.6$ \\
\hline P-value & 0.77 & 0.73 & 0.29 & 0.92 \\
\hline \multicolumn{5}{|l|}{ Sex } \\
\hline Male & $113.5 \pm 5.5$ & $90.9 \pm 4.9$ & $58.4 \pm 2.8$ & $29.1 \pm 0.3$ \\
\hline Female & $105.2 \pm 3.9$ & $100.4 \pm 6.2$ & $65.5 \pm 3.1$ & $29.0 \pm 0.6$ \\
\hline P-value & 0.27 & 0.27 & 0.07 & 0.98 \\
\hline
\end{tabular}


of plasma and hematocrit (\%) in whole blood. Herbal extract additives at two different levels did not have a significant effect on the above-mentioned parameters $(\mathrm{P}>0.05)$. In addition to the dietary treatments, the effect of sex was also not meaningful on hematocrit and plasma lipid profile.

Sarica et al. (2005) found that garlic and thyme extracts have no significant effect on plasma cholesterol concentration. Also, Horton et al. (1991) stated that plasma cholesterol content at the end of 35 days in broiler chicks was not influenced by garlic powder. This was in accordance with some other investigations showing that garlic powder and oils did not decrease blood cholesterol (Berthold et al., 1998). In adverse, Bordia et al. (1975) at the end of 35 days found a $53 \%$ decrease in plasma cholesterol followed by the addition of 2 and 3 percent garlic powder to the diet.

There is little information available about the effect of garlic and thyme extracts on triglyceride, HDL and hematocrit concentrations. Using garlic powder at the levels of $1.5,3$ and $4 \%$ of ration in broiler chicks decreased the concentartion of triglycerides of plasma and liver (Bakalli et al., 1997). Demir et al. (2003) investigated the effect of some herb extracts such as garlic and thyme on broiler's hematology and reported no influence on plasma triglyceride.

Carcass composition is presented in Table-4. Dietary treatments did not induce any significant effect on the carcass composition parameters including carcass yield (\%), breast (\%), thigh (\%), and abdominal fat pad (\%). Sex of chickens did not have any significant effect on the carcass composition (data not shown)

Sarica et al. (2005) found that the use of two herbs, extracts of thyme and garlic, had no significant effect on different components of carcass as well as heart, liver, gizzard and spleen weight of broiler chickens. Hernandez et al. (2004) reported that using combination of two herb extracts had no significant effect on carcass characteristics. The results of the present study are also in agreement with the results of Mandal et al. (2000) that showed essential oils had no significant effect on performance of carcass yield of broiler chickens. In contrast, Alçiçek et al. (2003) found that use of herb extract resulted in improvement of carcass but had no significant effect on abdominal fat percentage. Jamroz and Kamel (2002) showed that broiler chickens fed with herb extract had higher breast weight compared to CON group.

The results in this study showed that application of two herb extracts, garlic and thyme, had no significant effect on performance and percentage of carcass components (thigh, breast, abdominal fat, and carcass weight). Although, this experiment was performed in a disinfected condition that may have resulted in a decreased performance of these extracts. More effective influences of these extracts could probably be seen in chickens rearing in the non-hygienic situation. Therefore, more studies with different growth facility need to be performed to analyze the effect of herb extracts on the performance, carcass yield, and hematology of poultry.

Table 4. Effect of the plant extracts on carcass composition of broilers

\begin{tabular}{lcccc}
\hline & Carcass yield (\%) & Breast (\%) & Thigh (\%) & Abdominal fat (\%) \\
\hline \hline CON & $62.0 \pm 1.90$ & $35.1 \pm 1.52$ & $32.0 \pm 1.13$ & $2.80 \pm 0.36$ \\
\hline Thyme extract & & & & \\
T $0.3 \%$ & $61.7 \pm 0.70$ & $32.5 \pm 0.94$ & $30.2 \pm 0.42$ & $3.20 \pm 0.30$ \\
T 0.6\% & $63.3 \pm 0.70$ & $33.4 \pm 0.67$ & $30.3 \pm 0.47$ & $3.21 \pm 0.23$ \\
\hline Garlic extract & & & & \\
G 0.3\% & $61.9 \pm 0.36$ & $33.2 \pm 0.24$ & $30.4 \pm 0.52$ & $3.21 \pm 0.23$ \\
G 0.6\% & $61.7 \pm 0.73$ & $32.1 \pm 0.60$ & $31.4 \pm 0.55$ & $2.90 \pm 0.24$ \\
P-value & 0.48 & 0.07 & 0.43 & 0.09 \\
\hline Sex & & & & 3.07 \\
Male & 62.8 & 33.5 & 31.3 & 2.87 \\
Female & 61.5 & 33.1 & 30.4 & 0.27 \\
P-value & 0.15 & 0.23 & 0.23 & \\
\hline
\end{tabular}




\section{REFERENCES}

Alçiçek, A., Bozkurt, M. and Çabuk, M. 2003. The effects of an essential oil combination derived from selected herbs growing wild in turkey on broiler performance. S. Afr. J. Anim. Sci. 33:89-94.

Azaz, D., Demirci, F., Satil, F., Kürkcüog, `lu. and Baser, K.H.C. (2002). Antimicobial activity of some Satureja oils. Z. Naturforsch. 57:817-821.

Bakalli, I., Pesti, G. M. and Konjueca, V. H. 1997. Modulation of cholesterol levels in broiler meat by dietary garlic and copper. Poult Sci. 76:1264-1271

Bassett, R. 2000. Oreganos positive impact on poultry production. World Poultry-Elsevier 16:31-34.

Berthold, H. K., Sudhop, T. and Von Bergmann, K. 1998. Effect of garlic oil preparation on serum lipoproteins and cholesterol metabolism. J. Am. Med. 279:1900-1902.

Bolukbasi, Ş. C., Erhan, M.K. and özkan, A. 2006. Effect of dietary thyme oil and vitamin $\mathrm{E}$ on growth, lipid oxidation, meat fatty acid composition and serum lipoproteins of broilers. S. Afr. J. Anim. Sci. 36:189-196.

Bordia, A., Bansol, H. C., Arora, S. K. and Singal, S. V. 1975. Effect of the essential oils of garlic and onion on dementary hyperlipemia. Atherosclerosis. 21:15-19.

Botsoglou, N. A., Christaki, E., Florou-Paner, P., Giannenas, I., Papageorgiou, G. and Spais, A. B. 2004. The effect of a mixture of herbal essential oils or ă-tocopheryl acetate on performance parameters and oxidation of body lipid in broiler. S. Afr. J. Anim. Sci. 34:52-61.

Botsoglou, N. A., Florou-Paner, P., Christaki, E., Fletouris, D. G. and Spais, A. B. 2002. Effect of dietary oregano essential oil on performance of chickens and on iron induced lipid oxidation of breast, thigh and abdominal fat tissues. Br. Poult Sci. 43:223-230.

Cross, D. E., Acamovic, T., Deans, S. G. and Mcdevitt, R. M. 2002. The effect of dietary inclusions of herbs and their volatile oils on the performance of growing chickens. Br. Poult. Sci. 43:33-35.

Demir, E., Sarica, S., Ozcan, M. A. and Suicmez, M. 2003. The use of natural feed additives as alternatives for an antibiotic growth promoter in broiler diets. Br. Poult Sci. 44:S44-S45.

Dorman, H. J. D. and Deans, S. G. 2000. Antimicrobial agent from plants: antimicrobial activity of plant volatile oils. J. Appl. Microbiol. 88:308-316

Faleiro, M. L., Miguel, M. G., Ladeiro, F., Venanclo, F., Taveres, R., Brito, J. C., Figueiredo, A. C., Barroso, J. G. and Pedro,
L. G. 2003. Antimicrobial activity of essential oils isolated from Portuguese endemic species of Thymus. Lett. Appl. Microbial. 36:35-40.

Gill, C. 2001. Safe and sustainable feed ingredients. Feed Int. 22: 40-45.

Hernandez, F., Madrid, J., Garcia, V., Orengo, J. and Megias, M. D. 2004. Influence of two plants extracts on broiler performance, digestibility and digestive organ size. Poult Sci. $83: 169-174$.

Hertrampf, J. W. 2001. Alternative antimicrobial performance promoters. Poultry. Int. 40:50-52.

Horton, G. M., Fennel, M. J. and Parsad, B. M. 1991. Effect of dietary garlic(Allium Sativum) on performance, carcass composition and blood chemistry changes in broiler chickens. Can. J. Anim Sci. 71:939-942.

Jamroz, D. and Kamel, C. 2002. Plant extracts on immunity, health and performance. J. Anim. Sci. 80:41.

Knarreborg, A., Simon, M. A., Engberg, R. M., Jenson, B. B. and Tannoek, G. W. 2002. Effects of dietary fat source and subtherapeatic levels of antibiotics on the bacterial community in the ileum of broiler chickens at various ages. Appl Env. Microbial. 68: 5918-5924.

Konjufca, V. H., Pesti, G. M. and Bakalli, R. I. 1997. Modulation of cholesterol levels in broiler meat by dietary garlic and copper. Poult Sci. 76:1264- 1271.

Langhout, P. 2000. New additives for broiler chickens. World Poultry-Elsevier. 16:22-27.

Mandal, L., Biswas, T. and Sakar, S. K. 2000. Broilers perform well on herbs or enzymes in mize diet. World PoultryElsevier. 16:19-21.

Mikulski, D., Zdunczyk, Z., Jankowski, J. and Juskiewicz, J. 2008. Effects of organic acids or natural plant extracts added to diets for turkeys on growth performance, gastrointestinal tract metabolism and carcass characteristics. J. Anim. Feed Sci. 17: 233-246.

Patterson, T. A. and Barkholder, K. M. 2003. Application of prebiotics and probiotics in poultry production. Poult Sci. 82: 627-637.

Sarica, S., Ciftci, A., Demir, E., Kilinc, K. and Yildirim, Y. 2005. Use of antibiotic growth promoter and two herbal natural feed additives with and without exogenous enzymes in wheat based broiler diets. S. Afr. Anim. Sci. 35:61-72.

SAS. 1999. SAS/STAT User's Guide(Version 8.01 Edition). SAS Inst. Inc., Cary, NC.

Schwarz, S., Kehrenberg, C. and Walsh, T. R. 2001. Use of antimicrobial agents in veterinary medicine and food animal 
production. Int. J. Antimicrob. Agents. 17:431-437.

Thakar, N. M., Chairmam, D. M., Mcelroy, A. R., Novak, C. L. and Link, R. L. 2004. Pharmacological scrcening of some medicinal plants as antimicrobial and feed additives. Msc Dissertation. Department of Animal Science Virginia Polytechnic Institute and State University, Blacksburg, Virginia USA.
Tucker, L. 2002. Botanical broilers: plant extracts to maintain poultry performance. Feed Int. 23:26-29.

Williams, P. and Losa, R. 2001. The use of essential oils and their compounds in poultry nutrition. World Poultry- Elsevier. $17: 14-15$.

(Received May 30, 2012; Revised Jun. 18, 2012; Accepted Jun. 19, 2012) 